\title{
Sex-linkage of two enzyme loci in Oncorhyncus mykiss (rainbow trout)
}

\author{
FRED W. ALLENDORF*, WILLIAM A. GELLMAN \& GARY H. THORGAARD $\dagger$ \\ Division of Biological Sciences, University of Montana, Missoula, MT 59812 and $†$ Department of Zoology, Washington \\ State University, Pullman, WA 99164, U.S.A.
}

\begin{abstract}
We report the first sex-linked loci in Oncorhynchus mykiss (rainbow trout). Previous cytological and breeding experiments have demonstrated an $\mathrm{XX} / \mathrm{XY}$ sex determining system in this and other salmonid species. Joint segregation data from fathers indicated an average of 8.1 per cent recombination between $H E X-2$ and the sex determining locus $(S E X)$. The average recombination between $H E X-2$ and $S S O D-1$ in fathers was 26.8 per cent. No evidence of non-random segregation of $H E X-2$ and $S S O D-1$ was found in mothers; this difference in recombination rates between males and females is concordant with previous studies with rainbow trout and other salmonid species. These results also suggest the possibility that proper chromosomal pairing and segregation in salmonid males does not require a crossover event. Unlike the extreme $\mathrm{XX} / \mathrm{XY}$ heteromorphy in mammals, functional alleles for $H E X-2$ and $S S O D-1$ occur on both the $\mathrm{X}$ and $\mathrm{Y}$ chromosomes. Significant non-random associations (i.e. gametic disequilibrium) occur between genotypes at $H E X-2$ and $S E X$ in the hatchery population used for the inheritance study. This gametic disequilibrium has resulted in large changes in allele frequency at $H E X-2$ from one generation to the next and an excess of heterozygotes in comparison to expected binomial (i.e. Hardy-Weinberg) proportions.
\end{abstract}

Keywords: allozyme, heterozygosity, Oncorhynchus, pseudoautosomal, salmonid, sex-linkage.

\section{Introduction}

Inheritance studies of enzyme loci have revealed a variety of sex-determining genetic systems in vertebrates (Adkins-Regan, 1985). The familiar extreme heteromorphic XY male system conserved in all mammal species is exceptional. Fish, amphibians, and reptiles all show a wide variety of sex determining systems (Bull, 1983). A female heterogametic ZW system is conserved among bird species; however, one of the two reported Z-linked enzyme loci in birds has been found to have a functional counterpart on the W-chromosome (Morizot et al., 1987).

Muller (1914) proposed that the evolution of heteromorphic sex chromosomes involved the suppression of crossing-over between a proto- $X$ and proto-Y. Crossover suppression can evolve through the action of modifier loci that reduce recombination between the sex-determining regions and a syntenic locus when there is a selectively maintained sex differ-

\footnotetext{
*Correspondence.
}

ence in allele frequencies at the syntenic locus (Charlesworth \& Charlesworth, 1980). The Y chromosome may then degenerate owing to an accumulation of lethal mutations that are shielded from homozygosity by their counterparts on the $X$ chromosome, without the remedying effects of X-Y recombination (Charlesworth, 1991). Complete crossover suppression between sex chromosomes, however, is not advantageous because some pairing is required for precise disjunction during male meiosis (Koller \& Darlington, 1934). This necessity for $X-Y$ pairing accounts for the presence of a homologous segment between the human $\mathrm{X}$ and $\mathrm{Y}$ that derives its name from a mode of inheritance caused by obligate $\mathrm{X} / \mathrm{Y}$ exchange: the 'pseudoautosomal' region (Burgoyne, 1986). Pseudoautosomal regions that undergo recombination during male meiosis also have been described in the chimpanzee (Weber et al., 1988) and mouse (Keitges et al., 1985).

Both male and female heterogamety are common in fish species (reviewed in Ebeling \& Chen, 1970; Gold, 1979; Bull, 1984; Price, 1984). In at least one instance, 
there is a polymorphism for male and female heterogamety within populations. There are three sex chromosomes in the platyfish (Xiphophorus maculatus); in most populations of this species, there are three types of females (WY, WX and XX) and two types of males (XY and YY) (Kallman, 1973).

Fishes of the family Salmonidae have been a frequent subject for evolutionary genetic investigation because of their autopolyploid ancestry (Allendorf \& Thorgaard, 1984). Cytological differences indicate that males are the heterogametic sex in this family (reviewed in Hartley, 1987). These observations have been supported by all-female gynogenetically-produced progeny and breeding experiments with sex-reversed females (Donaldson \& Hunter, 1982).

In spite of a relative wealth of linkage information in salmonids (May \& Johnson, 1990), there is little information on sex-linkage in these fish (May et al., 1989). $\mathrm{X}$-linked loci are readily detected in mammals because the degenerate $\mathrm{Y}$ chromosome lacks functional alleles. This is likely to be untrue in salmonids because of the viability of $\mathrm{YY}$ individuals produced in sex-reversal studies (Chevassus et al., 1988; Scheerer et al., 1991). Moreover, no loci have been reported in salmonids that show different copy numbers or differences in allele frequency between males and females. Devlin $e t$ al. (1991) recently have discovered a Y chromosomespecific DNA probe developed by subtractive hybridization in chinook salmon (Oncorhynchus tshawytscha).

The purpose of the present study is to detect loci that are linked to the sex-determining factor in rainbow trout (Oncorhynchus mykiss). We describe two enzyme loci, $H E X-2$ and $S S O D-1$, in rainbow trout that are linked to a region that contains the major sex determining locus. We also describe significant changes in allele frequency from generation to generation and an excess of heterozygous genotype frequencies at $H E X-2$ in a hatchery population of rainbow trout that are a result of the sex-linkage.

\section{Methods}

Fish used in this study are from the Arlee stock of rainbow trout, maintained at the Jocko River State Trout Hatchery, Arlee, Montana. The history of the stock is presented by Leary et al. (1983). Fish used as parents had their gametes removed at the hatchery and their tissues immediately sampled and electrophoresed in the laboratory to determine their genotypes at several enzyme loci.

Progeny were reared until an age when sex could be determined by examining the gonads under low power magnification (Lincoln \& Scott, 1983; Malison et al., 1986). This was done 6 months after hatching, when the fish were more than $100 \mathrm{~mm}$ in length. Fish were stored frozen at $-80^{\circ} \mathrm{C}$ until dissection.

Horizontal starch gel electrophoresis was used to identify the protein products for all gene loci. Gel preparation, buffers and staining procedures are those of Harris \& Hopkinson (1976) and Allendorf et al. (1977). We use the genetic nomenclature described for the identification of enzymes and enzyme loci of fishes (Shaklee et al., 1990); this system is modelled on the human nomenclature but has been modified to allow its use with the variety of fish species.

Four families initially were examined to detect sexlinked loci. The father of each family was chosen to be heterozygous for as many enzyme loci as possible. As males are the heterogametic sex, we expected to detect sex-linkage only when the father was heterozygous.

During the initial screening two isozyme loci, $H E X-2$ and $S S O D-1$, out of nine surveyed, showed statistically significant associations with phenotypic sex. All statistical tests performed on segregation ratios are based on exact binomial probabilities. The following loci, with enzyme name and E.C. number in parentheses, were also surveyed during the preliminary screening: EST-1 (esterase, 3.1.1.-); sIDDH (L-iditol dehydrogenase, 1.1.1.14); $m I D H P-2$ and $s I D H P-1$ (isocitrate dehydrogenase, 1.1.1.42); $L D H-B 2$ (L-lactate dehydrogenase, 1.1.1.27); $s M D H-B 1,2$ (malate dehydrogenase, 1.1.1.37); $P G M-1 r$ (regulatory locus for phosphoglucomutase (Allendorf et al., 1983), 5.4.2.2).

Hexosaminidase (HEX) has been intensively studied in humans because individuals with Tay-Sachs disease lack activity for one form of this enzyme. Multiple loci code for different forms of HEX (E.C. 3.2.1.52) in humans (Mahuran et al., 1985). Two buffer systems were used to detect genetic variation at loci encoding HEX: an amine-citrate buffer $(\mathrm{pH} 6.1)$ described by Clayton \& Tretiak (1972) and the $\mathrm{pH} 8.5$ buffer of Ridgway et al. (1970). The positive, glucose-specific HEX strain described by Harris \& Hopkinson (1976) was used with one alteration: a small amount of dimethyl sulphoxide (less than $1 \mathrm{ml}$ ) was used as the substrate solvent rather than ethyl alcohol. HEX activity was detected with both glucose-derived and galactose-derived staining substrates. This is indicative of beta- $\mathrm{N}$-acetylhexosaminidase activity (E.C. 3.2.1.52; Calvo et al., 1978).

Genetic variation for cytosolic superoxide dismutase (E.C. 1.15.1.1; sSOD-1) was first described in rainbow trout by Utter \& Hodgins (1971). Cytosolic SSOD-1 activity predominates in liver tissue although activity is present in several other tissues (Allendorf et al., 1977). The products of a second locus (sSOD-2) for this enzyme are present in homogenates from eye. Two common $S S O D-1$ electromorphs exist in rainbow trout 
and are present in the Arlee population $\left({ }^{*} 100\right.$ and $* 150$ ). The inheritance of this variation in rainbow trout was first described by Utter et al.(1973).

\section{Results}

\section{Hexosaminidase}

Results indicate that two loci encode HEX in rainbow trout. Evidence for the products of only a single locus $(H E X-2)$ was found in fish large enough to be classified as male or female (greater than $100 \mathrm{~mm}$ ). The strongest activity for the HEX-2 enzyme occurs in liver tissue although activity for the HEX-2 isozyme was also observed in tissue homogenates from gill, fin and kidney. Little or no HEX-2 activity was found in the other tissues that were examined (eye, muscle, heart, stomach and brain).

Another more cathodal zone of HEX activity was detected in homogenates from whole fry that had not yet absorbed their yolk sac (R. Danzmann, personal communication). All individuals examined had a single band of activity for this form of the enzyme regardless of their genotype at HEX-2; thus, this zone is apparently encoded by a distinct locus $(H E X-1)$. No activity for the enzyme produced by this locus was detected in fish after absorption of the yolk sac.

Three $H E X-2$ alleles were found in the Arlee population ${ }^{*} 100, * 75$ and $* 80$, on the basis of relative electrophoretic mobility). Heterozygotes at this locus show a three-banded pattern typical of a dimeric enzyme. The relatively slight difference in mobility between the two slower alleles was not recognized in our earlier studies with this locus; in addition, $* 75 / 80$ heterozygotes were not used to test inheritance in this study because of the difficulty in distinguishing some of the resulting progeny phenotypes (e.g. *80/100 versus $* 75 / 100)$. In order to present genotypes more clearly in the tables, $A$ and $A^{\prime}$ designate alternative alleles at $H E X-2 ; A$ always refers to the ${ }^{*} 100$ allele but $A^{\prime}$ refers to either the ${ }^{*} 75$ or ${ }^{*} 80$ allele. Similarly, $B$ and $B^{\prime}$ have been used to designate the ${ }^{*} 100$ and $* 150$ alleles at SSOD-1.

\section{Joint segregation}

$H E X-2$ phenotypes of progeny were consistently associated with sex when the father was heterozygous (Table 1). The less frequent linkage class was assumed to be recombinants if the null hypothesis of independent assortment between $H E X-2$ and sex in the progeny was rejected (i.e. exact binomial probability $<0.05$ ); for example, in family M1 it is assumed that the $A$ allele was on the paternal $\mathrm{Y}$
Table 1 Joint inheritance of $H E X-2$ and sex. Heterozygous parental genotypes are bold

\begin{tabular}{|c|c|c|c|c|c|c|c|}
\hline \multirow[b]{2}{*}{ Family } & \multicolumn{2}{|c|}{$\begin{array}{l}\text { Parental geno- } \\
\text { types }\end{array}$} & & \multicolumn{3}{|c|}{$\begin{array}{l}\text { Progeny geno- } \\
\text { types }\end{array}$} & \multirow[b]{2}{*}{$r^{\mathrm{a}}$} \\
\hline & Female & Male & & $A A$ & $A A^{\prime}$ & $A^{\prime} A^{\prime}$ & \\
\hline L25 & $\boldsymbol{A A ^ { \prime }}$ & $\boldsymbol{A} \boldsymbol{A}^{\prime}$ & $\begin{array}{l}\text { Male } \\
\text { Female }\end{array}$ & $\begin{array}{l}2 \\
6\end{array}$ & $\begin{array}{l}7 \\
8\end{array}$ & $\begin{array}{l}9 \\
0\end{array}$ & $0.118^{* *}$ \\
\hline L26 & $A A$ & $\boldsymbol{A} \boldsymbol{A}^{\prime}$ & $\begin{array}{l}\text { Male } \\
\text { Female }\end{array}$ & $\begin{array}{r}15 \\
1\end{array}$ & $\begin{array}{r}2 \\
11\end{array}$ & - & $0.103^{* * *}$ \\
\hline L29 & $\boldsymbol{A} \boldsymbol{A}^{\prime}$ & $A^{\prime} A^{\prime}$ & $\begin{array}{l}\text { Male } \\
\text { Female }\end{array}$ & $\begin{array}{l}- \\
-\end{array}$ & $\begin{array}{l}3 \\
7\end{array}$ & $\begin{array}{l}2 \\
5\end{array}$ & n.s. \\
\hline L30 & $\boldsymbol{A} A^{\prime}$ & $A^{\prime} A^{\prime}$ & $\begin{array}{l}\text { Male } \\
\text { Female }\end{array}$ & $\begin{array}{l}- \\
-\end{array}$ & $\begin{array}{l}8 \\
6\end{array}$ & $\begin{array}{l}4 \\
7\end{array}$ & n.s. \\
\hline M1 & $A^{\prime} A^{\prime}$ & $\boldsymbol{A} \boldsymbol{A}^{\prime}$ & $\begin{array}{l}\text { Male } \\
\text { Female }\end{array}$ & $\begin{array}{l}- \\
-\end{array}$ & $\begin{array}{r}23 \\
3\end{array}$ & $\begin{array}{r}5 \\
28\end{array}$ & $0.136^{* * *}$ \\
\hline M2 & $\boldsymbol{A} \boldsymbol{A}^{\prime}$ & $A^{\prime} A^{\prime}$ & $\begin{array}{l}\text { Male } \\
\text { Female }\end{array}$ & - & $\begin{array}{l}43 \\
23\end{array}$ & $\begin{array}{l}27 \\
30\end{array}$ & $0.407^{*}$ \\
\hline M4 & $\boldsymbol{A} A^{\prime}$ & $A^{\prime} A^{\prime}$ & $\begin{array}{l}\text { Male } \\
\text { Female }\end{array}$ & $\begin{array}{l}- \\
-\end{array}$ & $\begin{array}{l}21 \\
20\end{array}$ & $\begin{array}{l}31 \\
19\end{array}$ & n.s. \\
\hline M5 & $A^{\prime} A^{\prime}$ & $\boldsymbol{A} \boldsymbol{A}^{\prime}$ & $\begin{array}{l}\text { Male } \\
\text { Female }\end{array}$ & $\begin{array}{l}- \\
-\end{array}$ & $\begin{array}{r}1 \\
26\end{array}$ & $\begin{array}{r}25 \\
1\end{array}$ & $0.038^{* * *}$ \\
\hline M6 & $\boldsymbol{A} \boldsymbol{A}^{\prime}$ & $A A$ & $\begin{array}{c}\text { Male } \\
\text { Female }\end{array}$ & $\begin{array}{l}3 \\
3\end{array}$ & $\begin{array}{l}8 \\
1\end{array}$ & - & n.s. \\
\hline M7 & $A^{\prime} A^{\prime}$ & $\boldsymbol{A} \boldsymbol{A}^{\prime}$ & $\begin{array}{c}\text { Male } \\
\text { Female }\end{array}$ & $\begin{array}{l}- \\
-\end{array}$ & $\begin{array}{r}5 \\
32\end{array}$ & $\begin{array}{r}32 \\
5\end{array}$ & $0.135^{* * *}$ \\
\hline
\end{tabular}

n.s.: not significant.

${ }^{\mathrm{a}}$ Estimated rate of recombination.

${ }^{*} P<0.05$; ${ }^{*} P<0.01 ;{ }^{* * *} P<0.001$.

chromosome and the $A^{\prime}$ allele was on the paternal X chromosome (Nordheim et al., 1983). A significant association between $H E X-2$ and sex was found in one of four families in which only the maternal parent was heterozygous at $H E X-2(\mathrm{M} 2)$. However, this deviation is not statistically significant if corrected for the five independent tests of this association (Rice, 1989).

Both parents were heterozygous at $H E X-2$ in family L25. The significant association between $H E X-2$ and sex in these progeny was assumed to be caused by linkage in the father. If the $A^{\prime}$ allele were on the $\mathrm{Y}$ chromosome in the father then $A^{\prime} A^{\prime}$ females would be under-represented in the progeny. Progeny heterozygous at $H E X-2$ were ignored in the classification as parental or recombinant type in the progeny because of the ambiguity of determining which allele was inherited from which parent.

The $S S O D-I$ phenotypes of progeny tended to be associated with sex when the father was heterozygous 
in those families that allowed pairwise analysis of sex and $S S O D-1$ (Table 2). All analyses were performed as described above for associations between $H E X-2$ and sex. This association between $S S O D-1$ and sex was confirmed in the three-point test crosses that are presented later.

A series of crosses was made to estimate the rate of recombination between $H E X-2$ and $S S O D-1$ in both males and females. These progeny were sampled

Table 2 Joint inheritance of $s S O D-1$ and sex. Heterozygous parental genotypes are bold

\begin{tabular}{|c|c|c|c|c|c|c|c|}
\hline \multirow[b]{2}{*}{ Family } & \multicolumn{2}{|c|}{$\begin{array}{l}\text { Parental geno- } \\
\text { types }\end{array}$} & & \multicolumn{3}{|c|}{$\begin{array}{c}\text { Progeny geno- } \\
\text { types }\end{array}$} & \multirow[b]{2}{*}{$r^{a}$} \\
\hline & Female & Male & & $B B$ & $B B^{\prime}$ & $B^{\prime} B^{\prime}$ & \\
\hline L25 & $\boldsymbol{B} \boldsymbol{B}^{\prime}$ & $\boldsymbol{B} \boldsymbol{B}^{\prime}$ & $\begin{array}{c}\text { Male } \\
\text { Female }\end{array}$ & $\begin{array}{l}4 \\
4\end{array}$ & $\begin{array}{l}9 \\
7\end{array}$ & $\begin{array}{l}5 \\
3\end{array}$ & n.s. \\
\hline L26 & $B^{\prime} B^{\prime}$ & $\boldsymbol{B} \boldsymbol{B}^{\prime}$ & $\begin{array}{c}\text { Male } \\
\text { Female }\end{array}$ & - & $\begin{array}{l}3 \\
8\end{array}$ & $\begin{array}{r}13 \\
2\end{array}$ & $0.192^{* *}$ \\
\hline L29 & $B B$ & $\boldsymbol{B} \boldsymbol{B}^{\prime}$ & $\begin{array}{c}\text { Male } \\
\text { Female }\end{array}$ & $\begin{array}{l}1 \\
2\end{array}$ & $\begin{array}{l}4 \\
7\end{array}$ & - & n.s. \\
\hline L30 & $B B$ & $\boldsymbol{B} \boldsymbol{B}^{\prime}$ & $\begin{array}{c}\text { Male } \\
\text { Female }\end{array}$ & $\begin{array}{l}8 \\
2\end{array}$ & $\begin{array}{r}4 \\
12\end{array}$ & - & $0.231^{* *}$ \\
\hline M7 & $\boldsymbol{B} \boldsymbol{B}^{\prime}$ & $\boldsymbol{B} \boldsymbol{B}^{\prime}$ & $\begin{array}{c}\text { Male } \\
\text { Female }\end{array}$ & $\begin{array}{r}13 \\
4\end{array}$ & $\begin{array}{l}20 \\
20\end{array}$ & $\begin{array}{r}4 \\
11\end{array}$ & $0.250^{*}$ \\
\hline
\end{tabular}

n.s.: not significant.

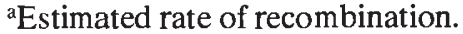

$* P<0.05$; $* * 0.01$. before they were large enough to determine their sex. The null hypothesis of independent assortment can be rejected in all four families in which the father was heterozygous for both $H E X-2$ and $S S O D-1$ (Table 3). However, there is no indication of non-independent assortment when the mother was doubly heterozygous (Table 3).

Some joint-segregation results in salmonids have shown an excess of recombinant over parental types. The process responsible for this result, known as pseudolinkage, results from meiotic abnormalities due to the ancestral tetraploidy of salmonid species (Wright et al., 1983; Allendorf \& Thorgaard, 1984). We tested for pseudolinkage by mating two males heterozygous at $H E X-2$ and $s S O D-2$ with known linkage phase $(A B /$ $\left.A^{\prime} B^{\prime}\right)$ to doubly homozygous females. These progeny were sampled before their sex could be determined. A significant excess of parental types as $H E X-2$ and $s S O D-1$ occurred in both families (Table 4). This suggests that the non-random segregation between these loci results from classical linkage and not pseudolinkage.

\section{Three-point test crosses}

Five males heterozygous for $H E X-2$ and $S S O D-1$ were used to construct five three-point test crosses to determine gene order (Table 5). Eight classes of progeny resulted from these three-point crosses: two parental classes, four single crossover classes and two double crossover classes. The most frequent classes were assumed to be the parental types (i.e. the result of no crossovers). The parental gamete types were designated as $\mathrm{X} A B$ and $\mathrm{Y} a b$ to reduce the number of

Table 3 Joint inheritance of $H E X-2(A)$ and $S S O D-1(B)$. Doubly-heterozygous parental genotypes are bold

\begin{tabular}{|c|c|c|c|c|c|c|c|c|c|}
\hline \multirow[b]{2}{*}{ Family } & \multicolumn{2}{|c|}{ Parental genotypes } & \multicolumn{6}{|c|}{ Progeny genotypes } & \multirow[b]{2}{*}{$r^{\mathrm{a}}$} \\
\hline & Female & Male & $\begin{array}{c}A A \\
B B\end{array}$ & $\begin{array}{c}A A^{\prime} \\
B B\end{array}$ & $\begin{array}{c}A^{\prime} A^{\prime} \\
B B\end{array}$ & $\begin{array}{l}A A \\
B B^{\prime}\end{array}$ & $\begin{array}{c}A A^{\prime} \\
B B^{\prime}\end{array}$ & $\begin{array}{c}A^{\prime} A^{\prime} \\
B B^{\prime}\end{array}$ & \\
\hline N1 & $A^{\prime} A^{\prime} B B$ & $\boldsymbol{A} \boldsymbol{A}^{\prime} \boldsymbol{B} \boldsymbol{B}^{\prime}$ & - & 53 & 22 & - & 27 & 52 & $0.318^{* * *}$ \\
\hline $\mathrm{N} 2$ & $\boldsymbol{A} \boldsymbol{A}^{\prime} \boldsymbol{B} \boldsymbol{B}^{\prime}$ & $A A B B$ & 46 & 54 & - & 45 & 38 & - & n.s. \\
\hline N3 & $A^{\prime} A^{\prime} B B$ & $\boldsymbol{A} \boldsymbol{A}^{\prime} \boldsymbol{B} \boldsymbol{B}^{\prime}$ & - & 28 & 71 & - & 71 & 20 & $0.253^{* * *}$ \\
\hline N4 & $\boldsymbol{A} \boldsymbol{A}^{\prime} \boldsymbol{B} \boldsymbol{B}^{\prime}$ & $A A B B$ & 41 & 38 & - & 47 & 54 & - & n.s. \\
\hline N5 & $A^{\prime} A^{\prime} B B$ & $\boldsymbol{A} \boldsymbol{A}^{\prime} \boldsymbol{B} \boldsymbol{B}^{\prime}$ & - & 57 & 13 & - & 9 & 65 & $0.153^{* * *}$ \\
\hline N6 & $\boldsymbol{A} \boldsymbol{A}^{\prime} \boldsymbol{B} \boldsymbol{B}^{\prime}$ & $A A B B$ & 50 & 45 & - & 40 & 44 & - & n.s. \\
\hline N7 & $A^{\prime} A^{\prime} B B$ & $\boldsymbol{A} \boldsymbol{A}^{\prime} \boldsymbol{B} \boldsymbol{B}^{\prime}$ & - & 25 & 16 & - & 10 & 26 & $0.338^{* *}$ \\
\hline N8 & $\boldsymbol{A} \boldsymbol{A}^{\prime} \boldsymbol{B} \boldsymbol{B}^{\prime}$ & $A A B B$ & 49 & 33 & - & 46 & 52 & - & n.s. \\
\hline
\end{tabular}

n.s.: not significant.

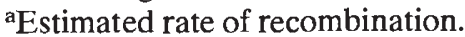

*** $P<0.001 ; * * P<0.01$. 
Table 4 Joint inheritance of $H E X-2(A)$ and $S S O D-I(B)$ with known linkage phase

\begin{tabular}{|c|c|c|c|c|c|c|c|}
\hline \multirow[b]{2}{*}{ Family } & \multicolumn{2}{|c|}{$\begin{array}{l}\text { Parental geno- } \\
\text { types }\end{array}$} & \multicolumn{4}{|c|}{ Progeny genotypes } & \multirow[b]{2}{*}{$r^{\mathrm{a}}$} \\
\hline & Female & Male & $\begin{array}{l}A A \\
B B\end{array}$ & $\begin{array}{c}A A^{\prime} \\
B B\end{array}$ & $\begin{array}{l}A A \\
B B^{\prime}\end{array}$ & $\begin{array}{l}A A^{\prime} \\
B B^{\prime}\end{array}$ & \\
\hline \multirow{3}{*}{ Q104 } & $A$ & $A^{\prime} \quad B^{\prime}$ & \multirow{3}{*}{16} & \multirow{3}{*}{7} & \multirow{3}{*}{6} & \multirow{3}{*}{11} & \multirow{3}{*}{$0.325^{*}$} \\
\hline & - & 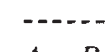 & & & & & \\
\hline & $A$ & $A \quad B$ & & & & & \\
\hline \multirow{2}{*}{ Q106 } & $A$ & $A^{\prime} \quad B^{\prime}$ & \multirow{2}{*}{17} & \multirow{2}{*}{6} & \multirow{2}{*}{5} & \multirow{2}{*}{9} & \multirow{2}{*}{$0.297^{\prime}$} \\
\hline & $A \quad B$ & $A \quad B$ & & & & & \\
\hline
\end{tabular}

${ }^{a}$ Estimated rate of recombination.

$* P<0.05$.

Table 5 Three-point test crosses for $S E X(\mathrm{X} ; \mathrm{Y}), H E X-2$ $(A ; a)$ and $\operatorname{SSOD-1}(B ; b)$ using males as the segregating parent

\begin{tabular}{lcrrrrrr}
\hline \multirow{2}{*}{ Crossover } & $\begin{array}{c}\text { Paternal } \\
\text { gamete }\end{array}$ & P1 & P5 & Q2 & Q4 & Q5 & Total \\
\cline { 3 - 7 } None & $\mathrm{X} A B$ & 35 & 30 & 19 & 36 & 23 & 301 \\
& $\mathrm{Y} a b$ & 33 & 29 & 35 & 36 & 25 & \\
Single & $\mathrm{X} a b$ & 2 & 0 & 0 & 0 & 0 & 12 \\
& $\mathrm{Y} A B$ & 1 & 3 & 5 & 1 & 0 & \\
Single & $\mathrm{X} A b$ & 4 & 14 & 10 & 6 & 13 & 94 \\
\multirow{4}{*}{ Double } & $\mathrm{Y} a B$ & 12 & 10 & 10 & 0 & 15 & \\
& $\mathrm{X} a B$ & 1 & 3 & 0 & 0 & 2 & \multirow{2}{*}{12} \\
& $\mathrm{Y} A b$ & 0 & 2 & 1 & 1 & 2 & \\
& & 88 & 91 & 80 & 80 & 80 & 417 \\
\hline
\end{tabular}

different genotypes represented in the table, i.e. the allele on the paternal $\mathrm{X}$-chromosome is designated as $A$ or $B$ regardless of its electrophoretic mobility; similarly, the allele on the Y-chromosome is designated as $a$ or $b$.

The results of the three-point test crosses do not allow us to determine the gene order. Double crossovers are expected to be less frequent than either of the single crossover classes. However, two of the crossover classes are approximately equally frequent in the five three-point families (Table 5). Thus, $H E X-2$ and SEX are very near each other, and both of these loci are somewhat distant from $S S O D-1$. These results are surprising in view of the high interference values reported for female rainbow trout (Allendorf et al., 1986); this would suggest that there is less interference in male than there is in female rainbow trout.

\section{Genotypic distributions in the population}

Linkage with a sex-determining locus will affect the genotypes at another locus if there are differences in allele frequency between males and females. Such differences between the sexes may arise by hybridization, genetic drift in small populations or natural selection. The rate of decay of non-random associations (i.e. gametic disequilibrium) between the sex locus $(S E X)$ and another locus will depend only on the rate of recombination $(r)$ in males because females will always be homozygous $(X X)$ at the sex determining locus.

We need to follow three alleles' frequencies $(p f, p x$ and $p y$ ) to describe expected genotypic frequencies at a sex-linked locus in which functional alleles are present on both the $\mathrm{X}$ and $\mathrm{Y}$ chromosomes (Clark, 1988). Let $p f$ equal the frequency of the $A$ allele in females. Let $p x$ equal the frequency of the $A$ allele on the $\mathrm{X}$ chromosome in males and py equal the frequency of the $A$ allele on the $\mathrm{Y}$ chromosome in males. And since $\mathrm{X}$ and $\mathrm{Y}$ chromosomes are equally frequent in males, the allele frequency of $A$ in males $(p m)$ will be $[(p x+p y) / 2]$. We can then describe the expected frequencies of the $A$ allele in the next generation ( $p f^{\prime}, p x^{\prime}$ and $\left.p y^{\prime}\right)$. Sons receive all of their $\mathrm{X}$ chromosomes from their mothers. Therefore,

$p x^{\prime}=p f$.

Sons receive all of their $\mathrm{Y}$ chromosomes from their fathers. However, we must take into account the possibility of recombination in males. Therefore,

$p y^{\prime}=(1-r) p y+r p x$.

Daughters receive half of their $\mathrm{X}$ chromosomes from their mothers and half from their fathers. Therefore,

$p f^{\prime}=\left(\frac{p f}{2}\right)+\frac{((1-r) p x+r p y)}{2}$.

We can use these equations to predict changes in genotype frequencies from generation to generation. Figure 1 shows expected changes in allele frequencies in females and males in the case where the initial frequencies are $p f=1$ and $p m=0$ for three different amounts of recombination. We can see two different processes coming to equilibrium in this figure. The difference in allele frequencies on the $\mathrm{X}$ chromosomes in males and females is approximately halved each generation, regardless of the amount of recombination; this is the familiar result in $\mathrm{XX} / \mathrm{XY}$ systems in which there are no functional alleles on the $Y$ chromosome. The second process is the equalization of the allele frequencies on the $\mathrm{X}$ and $\mathrm{Y}$ chromosomes in males which is delayed by decreased recombination between the locus in question and $S E X$ (Fig. 2). 
Fig. 1 Expected changes in allele frequency in females (upper line) and males (lower line) at a sex-linked locus in which functional alleles are found on both sex chromosomes. $r$ is the recombination between the locus under study and the $S E X$ locus in males.

Fig. 2 Expected changes in allele frequency for the $\mathrm{X}$ chromosome in females $(p f)$, the $\mathrm{X}$ chromosome in males $(p x)$ and the $Y$ chromosome $(p y)$. As in Fig. 1, the initial allele frequency in females is 1.0 and the initial allele frequency in males is $0.0 ; r=0.10$.
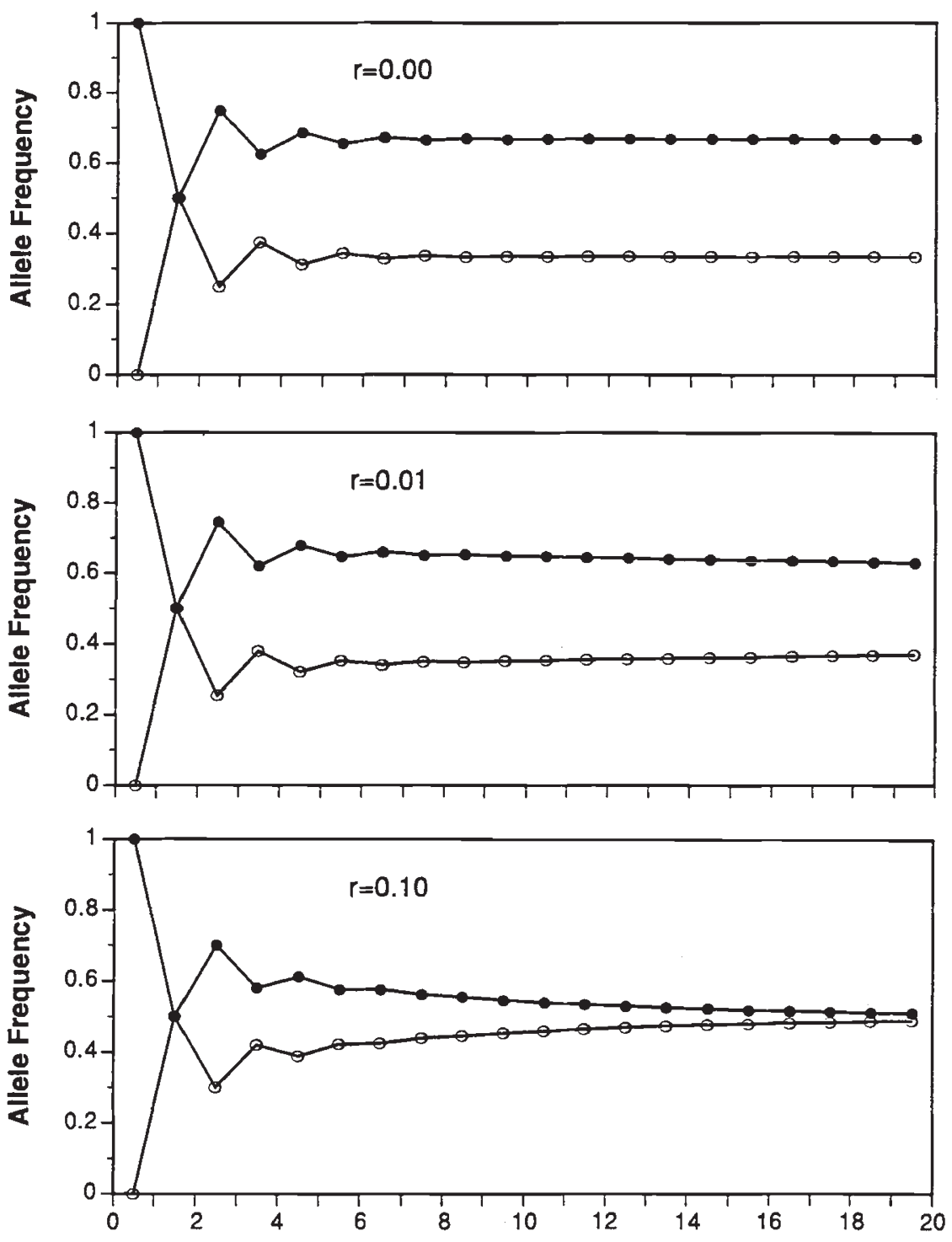

Generations

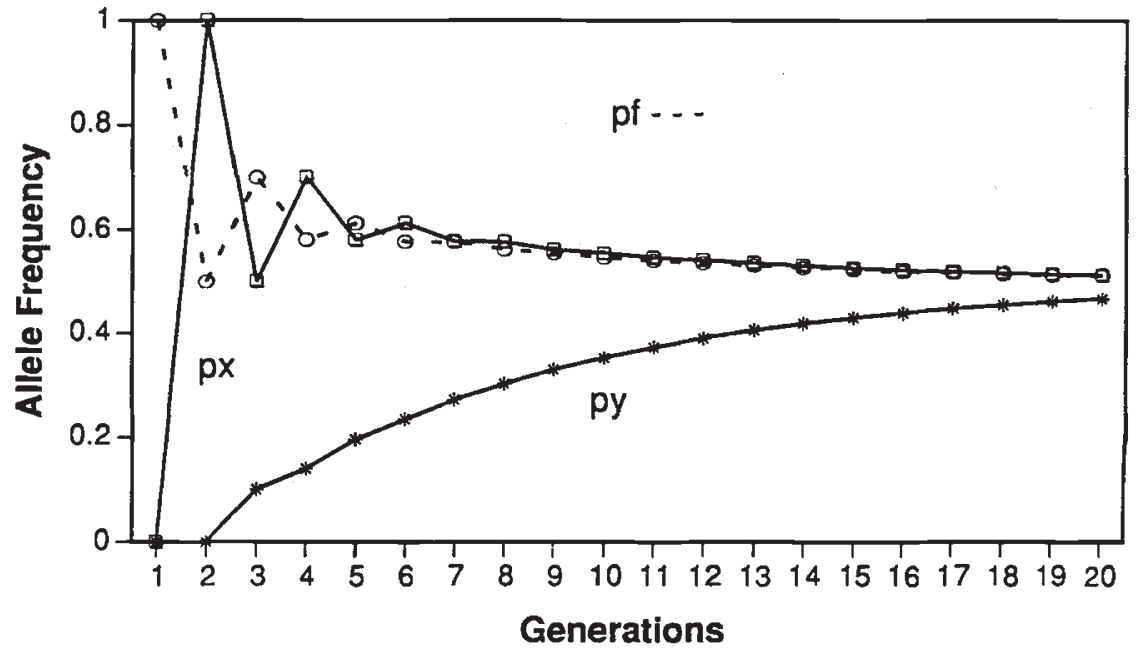


Allele frequency differences between males and females will result in an excess of heterozygous progeny relative to binomial (i.e. Hardy-Weinberg) expectations. We would therefore expect to find an excess of heterozygotes at sex-linked loci that differ in female and male allele frequencies. The heterozygous excess in females depends on differences in $p f$ and $p x$ which will decay at a rate of approximately 50 per cent each generation (Fig. 2). The heterozygous excess in males depends on differences in $p f$ and $p y$ which can decay at a much slower rate with tight linkage (Fig. 2). Therefore, heterozygous excess due to allele frequency differences between the sexes is expected to be greater in males than in females.

We can see all of these effects at $H E X-2$ in the Arlee population of rainbow trout (Table 6). It is difficult to interpret these results precisely with regard to the above expectations because of overlapping generations in the Arlee population; i.e. the parents of any individual cohort usually consisted of 2-year-old males and 3 -year-old females. The equations above are all based on the assumption of non-overlapping generations. Nevertheless, we can see large differences in allele fre-

Table 6 Associations between sex and $H E X-2$ in Arlee rainbow trout

\begin{tabular}{|c|c|c|c|c|c|c|}
\hline \multirow[b]{2}{*}{ Cohort } & \multirow[b]{2}{*}{ Sex } & \multicolumn{3}{|c|}{$H E X-2$ genotype } & \multirow[b]{2}{*}{ Freq. $(A)^{\mathrm{a}}$} & \multirow[b]{2}{*}{$F^{\mathrm{b}}$} \\
\hline & & $A A$ & $A A^{\prime}$ & $A^{\prime} \mathrm{A}^{\prime}$ & & \\
\hline 1980 & Female & 19 & 26 & 5 & 0.640 & -0.13 \\
\hline 1981 & $\begin{array}{l}\text { Female } \\
\text { Male }\end{array}$ & $\begin{array}{l}18 \\
36 \\
54\end{array}$ & $\begin{array}{l}29 \\
38 \\
67\end{array}$ & $\begin{array}{l}13 \\
13 \\
26\end{array}$ & $\begin{array}{l}0.542 \\
0.632 \\
0.595\end{array}$ & $\begin{array}{l}0.03 \\
0.06 \\
0.05\end{array}$ \\
\hline 1982 & $\begin{array}{l}\text { Female } \\
\text { Male }\end{array}$ & $\begin{array}{l}11 \\
17 \\
28\end{array}$ & $\begin{array}{r}69 \\
69 \\
138\end{array}$ & $\begin{array}{r}17 \\
101 \\
118\end{array}$ & $\begin{array}{l}0.469 \\
0.275 \\
0.342^{* * *}\end{array}$ & $\begin{array}{c}-0.43^{* * *} \\
0.07 \\
-0.08\end{array}$ \\
\hline 1984 & $\begin{array}{l}\text { Female } \\
\text { Male }\end{array}$ & $\begin{array}{l}36 \\
35 \\
71\end{array}$ & $\begin{array}{l}35 \\
61 \\
96\end{array}$ & $\begin{array}{r}9 \\
19 \\
28\end{array}$ & $\begin{array}{l}0.669 \\
0.570 \\
0.610^{*}\end{array}$ & $\begin{array}{r}0.01 \\
-0.08 \\
-0.03\end{array}$ \\
\hline 1985 & Male & 13 & 63 & 67 & 0.311 & -0.03 \\
\hline 1986 & Female & 8 & $10^{\circ}$ & 2 & 0.655 & -0.10 \\
\hline 1987 & $\begin{array}{l}\text { Female } \\
\text { Male }\end{array}$ & $\begin{array}{r}12 \\
9 \\
21\end{array}$ & $\begin{array}{r}16 \\
8 \\
24\end{array}$ & $\begin{array}{l}2 \\
2 \\
4\end{array}$ & $\begin{array}{l}0.666 \\
0.684 \\
0.673\end{array}$ & $\begin{array}{r}-0.20 \\
0.03 \\
-0.11\end{array}$ \\
\hline 1988 & Male & 4 & 9 & 7 & 0.425 & 0.08 \\
\hline
\end{tabular}

${ }^{a}$ Probability values on cohort allele frequency test for differences between males and females by contingency chisquare.

${ }^{\mathrm{b}}$ Fixation index (relative excess or deficit of heterozygotes). * $P<0.05$; ** $P<0.01$; *** $P<0.001$. quency in males and females from generation to generation and a tendency for an excess of heterozygotes. However, the excess of heterozygotes is statistically significant in only a single case.

\section{Discussion}

\section{Sex-linkage of HEX-2 and SSOD-1}

Significant non-random associations between $H E X-2$ and $S S O D-1$ were found in 10 of the 11 families for which the father was doubly heterozygous (Table 7); the probability of the distributions observed in the other family $(\mathrm{Q} 5)$ is less than 0.06 . If we include this family in our calculations, the average recombination rate between $H E X-2$ and $S S O D-1$ in males is 0.268 .

May and Johnson (1990) have reported that $H E X-2$ and $S S O D-1$ are also linked in salmonid fish in the genus Salvelinus; they report recombination rates of 0.15 and 0.27 in two crosses using male interspecific hybrids between brook trout ( $S$. fontinalis), lake trout (S. namaycush) and Arctic char (S. alpinus). However, May et al. (1989) report that the loci encoding hexosaminidase and superoxide dismutase are not linked to sex in crosses of hybrids between brook trout and lake trout.

There is no evidence of non-random segregation of $H E X-2$ and $S S O D-1$ in mothers (Table 3 ). However, the greater recombination rate in females does not appear to be associated with or a result of the linkage with $S E X$. Previous salmonid linkage studies have shown that recombination rates are generally greater in females than males (Johnson et al., 1987; May \& Johnson, 1990). Reduced autosomal recombination in the heterogametic sex is often observed (Bull, 1983; although see Burt et al. 1991).

These data indicate that $H E X-2$ and $S S O D-1$ are both on the chromosome carrying the major sex-determining locus $(S E X)$ in rainbow trout. Significant nonrandom association between $H E X-2$ and $S E X$ was found in every family for which the father was heterozygous at $H E X-2$ (Table 7). The mean recombination rate between $S E X$ and $H E X-2$ in 10 families is 0.081 .

Gene-centromere mapping via half-tetrad analysis of gynogenetically produced progeny (Allendorf et al., 1986) has indicated that $H E X-2$ in rainbow trout is near the centromere ( 0.017 recombination in females) and that $S S O D-1$ is distal $(0.497$ recombination in females). The proximity of $S E X$ to the centromere in rainbow trout is in agreement with cytogenetic results (Thorgaard, 1977; Lloyd \& Thorgaard, 1988) and evidence from other species of fish (reviewed in Gold, 1979). 
Table 7 Summary of recombination rates in males

\begin{tabular}{lcccc}
\hline Family & $\begin{array}{c}\text { Total } \\
\text { individuals }\end{array}$ & $H E X-2: S E X$ & sSOD-1:SEX & HEX-2:sSOD-1 \\
\hline L25 & 32 & $0.118^{* * *}$ & n.s. & - \\
L26 & 26 & $0.103^{* * *}$ & $0.192^{* * *}$ & - \\
L29 & 14 & - & n.s. & - \\
L30 & 26 & - & $0.231^{* * * *}$ & - \\
M1 & 59 & $0.136^{* * *}$ & - & - \\
M5 & 53 & $0.038^{* * *}$ & - & - \\
M7 & 74 & $0.135^{* * *}$ & $0.250^{*}$ & - \\
N1 & 154 & - & - & $0.318^{* * *}$ \\
N3 & 192 & - & - & $0.253^{* * *}$ \\
N5 & 144 & - & - & $0.153^{* * *}$ \\
N7 & 67 & - & - & $0.338^{* *}$ \\
P1 & 88 & $0.045^{* * *}$ & $0.216^{* * *}$ & $0.193^{* * *}$ \\
P5 & 91 & $0.088^{* * *}$ & $0.297^{* * *}$ & $0.319^{* * *}$ \\
Q2 & 80 & $0.075^{* * *}$ & $0.313^{* * * *}$ & $0.263^{* * *}$ \\
Q4 & 80 & $0.025^{* * *}$ & $0.088^{* * * *}$ & $0.088^{* * *}$ \\
Q5 & 80 & $0.050^{* * *}$ & $0.350^{* * *}$ & 0.5. \\
Q104 & 40 & - & - & $0.325^{*}$ \\
Q106 & 37 & - & - & $0.297^{*}$ \\
\hline
\end{tabular}

n.s.: not significant.

${ }^{*} P<0.05 ;{ }^{* *} P<0.01 ;{ }^{* * *} P<0.001$.

These data also suggest the intriguing possibility that chromosomal segregation in male salmonids does not necessarily involve reciprocal recombination (crossingover). In most organisms, there is at least one crossover event between each pair of homologous chromosomes because crossing-over is required to ensure proper pairing and segregation (Baker et al., 1976; Kaback et al., 1992). Our half-tetrad analysis of $S S O D-1$ has indicated virtually complete interference in females on this chromosome in this strain of rainbow trout; 340 of 344 gynogenetic progeny from females heterozygous at SSOD-1 were heterozygous (Allendorf et al., 1986). Thus, there appears to be exactly one crossover on this chromosome in females 99 per cent of the time. Yet, there is greater recombination in females than in males on this chromosome. This suggests that a substantial proportion of the meiotic events for this chromosome in males does not involve a recombinant event.

\section{Sex chromosome evolution in salmonids}

Heteromorphic sex chromosomes have been detected in three salmonid species: the rainbow trout, the sockeye salmon (Oncorhynchus nerka) and the lake trout. The heteromorphism in rainbow trout is in the size of the short arm of one of the subtelocentric chromosomes; this arm is reduced in length in the putative $\mathrm{Y}$ chromosome (Thorgaard, 1977). The difference in arm size between the $\mathrm{X}$ and $\mathrm{Y}$ chromosomes might result from a pericentric inversion. In addition, Lloyd \& Thorgaard (1988) have described heavy centromeric $\mathrm{C}$-banding on the $\mathrm{X}$ chromosome that is much lighter on the Y chromosome. The arm length heteromorphism is not fixed in all populations (Thorgaard, 1983; Ueda \& Ojima, 1984b). Furthermore, a polymorphism for the length of the arm occurs within some populations (Thorgaard, 1983). Thorgaard (1983) has suggested that some isolated populations of rainbow trout have retained the primitive characteristic of undifferentiated sex chromosomes whereas most populations have a high frequency of a rearrangement that cytologically differentiates the $\mathrm{X}$ and $\mathrm{Y}$ chromosomes.

A centric fusion apparently has occurred in sockeye salmon between the Y chromosome and an autosome to form a metacentric chromosome (Thorgaard, 1978; Ueda \& Ojima, 1984a). This sex determining system of $\mathrm{X}_{1} \mathrm{X}_{2} \mathrm{Y}$ in males and $\mathrm{X}_{1} \mathrm{X}_{1}-\mathrm{X}_{2} \mathrm{X}_{2}$ in females is consistent with the tetraploid origin of salmonids. It also appears that there is an intraspecific polymorphism in sockeye salmon (reviewed in Thorgaard, 1978). These results are consistent with a location for $S E X$ near the centromere because the fusion difference between males and females would not be maintained if there were crossing over.

The heteromorphism in lake trout occurs in the Qand C-banding pattern of the largest pair of submetacentric chromosomes (Phillips \& Ihssen, 1985). An 
intermediate-sized quinacrine bright heterochromatic band occurs at the end of the short arm of the $\mathrm{X}$ chromosome. This band does not occur on the $\mathrm{Y}$ chromosome.

May et al. (1989) have reported sex-linkage of three tightly linked enzyme loci ( $L d h-1$, Aat-5 and Gpi-3) in second generation hybrids between brook trout and Arctic char backcrossed to brook trout. These loci are not associated with sex in hybrids between brook trout and lake trout; this is in contrast to the general pattern of strong conservation of linkages among salmonids. On this basis, these authors conclude that the sexlinkage of these three loci is caused by a chromosomal rearrangement (i.e. centric fusion) that is unique to the Arctic char: a chromosomal arm responsible for sex determination has fused with an autosome containing the three enzyme loci.

\section{Genotypic distributions of loci linked with SEX}

The Arlee hatchery population of rainbow trout was created approximately 15 generations ago by hybridizing two populations (Leary et al., 1983). This suggestion is supported by the pattern of genetic variation observed at approximately 15 polymorphic allozyme loci (Leary et al., 1983; unpublished data). Thus, the non-random association between $H E X-2$ and SEX in this population is possibly a result of this originating hybridization event.

We suggest that more careful examination of population data may indicate other loci that may be sex-linked in salmonids. This is especially true if the genotype frequencies can be examined separately in males and females. Any locus that demonstrated a tendency for an excess of heterozygotes (especially in males) or a tendency for greater than expected allele frequency changes from generation to generation (relative to other loci) would be a likely candidate for sex-linkage. Such linkage should be verified by inheritance experiments.

\section{Acknowledgements}

This research was supported by grants from the National Science Foundation to F.W.A. and from the National Institutes of Health (NIEHS ES 04766 and NIH RR 06654) to G.H.T. We thank Bernie May and Ruth Phillips for their comments on an earlier version of this manuscript and Frank Stahl for his insightful comments on crossing-over and segregation.

\section{References}

ADKINS-REGAN, E. 1985. Mechanisms of sex determination in vertebrates. Sci. Prog., Oxford, 69, 551-565.
ALLENDORF, F. W., KNUDSEN, K. L. AND LEARY, R. F. 1983. Adaptive significance of differences in the tissue-specific expression of a phosphoglucomutase gene in rainbow trout. Proc. Natl. Acad. Sci. USA, 80, 1397-1400.

ALLENDORF, F. W., MTTCHELL, N., RYMAN, N. AND STÅHL, G. 1977. Isozyme loci in brown trout (Salmo trutta L.): detection and interpretation from population data. Hereditas, 86, 179-190.

ALLENDORF, F. W., SEEB, J. E., KNUDSEN, K. L., THORGAARD, G. H. AND LEARY, R. F. 1986. Gene-centromere mapping of 25 loci in rainbow trout. J. Hered., 77, 307-312.

ALLENDORF, F. W. AND THORGAARD, G. H. 1984. Tetraploidy and the evolution of salmonid fishes. In: Turner, B. J. (ed.) The Evolutionary Genetics of Fishes, pp. 1-53. Plenum Press, New York.

BAKER, B. S., CARPENTER, A. T. C., ESPOSITO, M. S., ESPOSITO, R. R. AND SANDLER, L. 1976. The genetic control of meiosis. Ann. Rev. Genet., 10, 53-134.

BULl, J. J. 1983. Evolution of Sex Determining Mechanisms. Benjamin/Cummings, Menlo Park, CA.

BURGoYNE, P. s. 1986. Mammalian X and Y crossover. Nature, 319, 258-259.

BURT, A., BELL, G. AND HARVEY, P. H. 1991. Sex differences in recombination. J. Evol. Biol., 4, 259-277.

CAlvo, P., Reglero, A. AND CABeZAS, J. A. 1978. Purification and properties of $\mathrm{b}-\mathrm{N}$-acetylhexosaminidase from the mollusc Helicella ericetorum Muller. Biochem. J., 175, 743-750.

CHARLESWORTH, B. 1991. The evolution of sex chromosomes. Science, 251, 1030-1033.

CHARLESWORTH, D. AND CHARLESWORTH, B. 1980. Sex differences in fitness and selection for centric fusions between sex-chromosomes and autosomes. Genet. Res., 35, 205-214.

CHeVAsSus, B., DEVAUX, A., CHOURROUT, D. AND JALABERT, B. 1988. Production of YY rainbow trout males by self-fertilization of induced hermaphrodites. J. Hered., 79, 89-92.

CLARK, A. G. 1988. The evolution of the Y chromosome with X-Y recombination. Genetics, 119, 711-720.

ClAYTON, J. W. AND TRETIAK, D. N. 1972. Amine-citrate buffer for $\mathrm{pH}$ control in starch gel electrophoresis. J. Fish. Res. Board Can., 29, 1169-1172.

DEVLIN, R. H., MCNEIL, B. K., GROVES, T. D. D. AND DONALDSON, E. M. 1991. Isolation of a Y-chromosomal DNA probe capable of determining genetic sex in chinook salmon. Can.J. Fish. Aquat. Sci., 48, 1606-1612.

DONALDSON, E. M. AND HUNTER, G. A. 1982. Sex control in fish with particular reference to salmonids. Can.J. Fish. Aquat. Sci., 39, 99-110.

EBELING, A. W. AND CHEN, T. R. 1970. Heterogamety in teleostean fishes. Trans. Am. Fish. Soc., 99, 131-138.

GOLD, J. R. 1979. Cytogenetics. In: Hoar, W. S., Randall, D. J. and Brett, J. R. (eds) Fish Physiology, vol. 8, pp. 353-405. Academic Press, New York.

HARRIS, H. AND HOPKINSON, D. A. 1976. Handbook of Enzyme Electrophoresis in Human Genetics. American Elsevier, New York.

HARTLEY, S. E. 1987. The chromosomes of salmonid fishes. Biol. Rev., 62, 197-214.

JOHNSON, K. R., WRIGHT, J. E. JR. AND MAY, B. 1987. Linkage relationships reflecting ancestral tetraploidy in salmonid fish. Genetics, 116, 579-591. 
KABACK, D. B., GUACCI, V., BARBER, D. AND MAHON, J. W. 1992. Chromosome size-dependent control of meiotic recombination. Science, 256, 228-232.

KALLMAN, K. D. 1973. The sex-determining mechanism of the platyfish, Xiphophorus maculatus. In: Schroder, J. H. (ed.) Genetics and Mutagenesis of Fish, pp. 19-28. Springer, New York.

KEITGES, E., RIVEST, M., SINISCALCO, M. AND GARTLER, S. M. 1985. $\mathrm{X}$-linkage of steroid sulphatase in the mouse is evidence for a functional Y-linked allele. Nature, 315, 226-227.

KOLLER, P. C. AND DARLINGTON, C. D. 1934. The genetical and mechanical properties of sex chromosomes. J. Genet., 29, 159-172.

LEARY, R. F., ALLENDORF, F. W. AND KNUDSEN, K. L. 1983. Developmental stability and enzyme heterozygosity in rainbow trout. Nature, 301, 71-72.

LiNCOLN, R. F. AND SCOTT, A. P. 1983. Production of all-female triploid rainbow trout. Aquaculture, 30, 375-380.

LLOYD, M. A. AND THORGAARD, G. H. 1988. Restriction endonuclease banding of rainbow trout chromosomes. Chromosoma, 96, 171-177.

MAHURAN, D., NOVAK, A. AND LOWDEN, J. A. 1985. The hexosaminidases of humans. Curr. Top. Biol. Med. Res., 12, 229-288.

MALISON, J. A., KAYES, T. B., BEST, C. D. AND AMUNDSON, C. H. 1986. Sexual differentiation and use of hormones to control sex in yellow perch (Perca flavescens). Can. J. Fish. Aquat. Sci., 43, 26-35.

MAY, B. AND JOHNSON, K. R. 1990. Composition linkage map of salmonid fishes (Salvelinus, Salmo and Oncorhynchus). In: O'Brien, S. J. (ed.) Genetic Maps: Locus Maps of Complex Genomes, pp. 151-159. Cold Spring Harbor, New York.

MAY, B., JOHNSON, K. R. AND WRIGHT, J. E. JR. 1989. Sex linkage in salmonids: evidence from a hybridized genome of brook trout and Arctic char. Biochem. Genet., 27, 291-301.

MORIZOT, D. C., BEDNARZ, J. C. AND FERRELL, R. E, 1987. Sex linkage of muscle creatine kinase in Harris' hawks. Cytogenet. Cell Genet., 44, 89-91.

MULlER, H. J. 1914. A gene for the fourth chromosome of Drosophila. J. Exp. Zool., 17, 325-336.

NORDHEIM, E. V., O'MALLEY, D. M. AND GURIES, R. P. 1983. Estimation of recombination frequency in genetic linkage studies. Theor. Appl. Genet., 66, 313-321.

oHno, s. 1967. Sex Chromosomes and Sex-Linked Genes. Springer-Verlag, Berlin.

PHILLIPS, R. B. AND IHSSEN, P. E. 1985. Identification of sex chromosomes in lake trout (Salvelinus namaycush). Cytogenet. Cell Genet., 39, 14-18.
PRICE, D. J. 1984. Genetics of sex determination in fishes - a brief review. In: Potts, G. G. and Wooton, R. J. (eds) Fish Reproduction: strategies and tactics, pp. 77-89. Academic Press, London, New York.

REFSTIE, T., STOSS, J. AND DONALDSON, E. 1982. Production of all female coho salmon (Oncorhynchus kisutch) by diploid gynogenesis using irradiated sperm and cold shock. Aquaculture, 29, 67-82.

RICE, W. R. 1989. Analyzing tables of statistical tests. Evolution, 43, 223-225.

RIDGWAY, G. J., Sherburne, S. W. AND LEWIS, R. D. 1970. Polymorphisms in the esterases of Atlantic herring. Trans. Am. Fish. Soc., 99, 147-151.

SCHEERER, P. D., THORGAARD, G. H. AND ALLENDORF, F. W. 1991. Genetic analysis of androgenetic rainbow trout. J. Exp. Zool., 260, 382-390.

SHAKLEE, J. B., ALLENDORF, F. W., MORIZOT, D. C. AND WHITT, G. S 1990. Gene nomenclature for protein-coding loci in fish. Trans. Am. Fish. Soc., 119, 2-15.

THORgAARD, G. H. 1977. Heteromorphic sex chromosomes in male rainbow trout. Science, 196, 900-902.

THORGAARD, G. H. 1978. Sex chromosomes in the sockeye salmon: a Y-autosome fusion. Can. J. Genet. Cytol., 20, 349-354.

THORGAARD, G. H. 1983. Chromosomal differences among rainbow trout populations. Copeia, 3, 650-662.

UEDA, T. AND OJIMA, Y. 1984a. Sex chromosomes in the kokanee salmon Oncorhynchus nerka. Bull. Jpn. Soc. Sci. Fish., 50, 1495-1498.

UEDA, T. AND OJIMA, Y. 1984b. Sex chromosomes in the rainbow trout Salmo gairdneri. Bull. Jpn. Soc. Sci. Fish., 50, 1499-1504.

UTTER, F. M. AND HODGINS, H. O. 1971. Tetrazolium oxidase phenotypes of rainbow trout (Salmo gairdneri) and Pacific salmon (Oncorhynchus spp.). Comp. Biochem. Physiol., 39B, 891-895.

UTTER, F. M., HODGINS, H. O., ALLENDORF, F. W., JOHNSON, A. G. AND MIGHELL, J. L. 1973. Biochemical variants in Pacific salmon and rainbow trout: their inheritance and application in population studies. In: Schroder, J. H. (ed.) Genetics and Mutagenesis of Fish, pp. 329-339. Springer, New York.

WEBER, B., WEISSENBACH, J. AND SCHEMPP, w. 1988. X-Y crossing over in the chimpanzee. Hum. Genet., 80, 301-303.

WRIGHT, J. E. JR., JOHNSON, K. R., HOLLISTER, A. AND MAY, B. 1983. Meiotic models to explain classical linkage, pseudolinkage and chromosome pairing in tetraploid derivative salmonid genomes. Isozymes Curr. Top. Biol. Med. Res., 10, 239-260. 